Бојан Ђорђевић

Универзитет у Београду

Филолошки факултет

nalesko1965@gmail.com

https://doi.org/10.18485/ai_diskurs_pobede.2019.ch5

821.163.41.09-31 Пекић Б.

\title{
ДИСКУРС ПОБЕДЕ У ПЕКИЋЕВОМ ЗЛАТНОМ РУНУ
}

У раду се, на основу две наративне секвенце Пекићевог романа Злайно руно, говори о наративним моделима који моделирају дискурс победе и пораза. Показује се антагонизам херојске (митске) и рационалне (симеонске) свести о цени победе, њеној вредности и значењу. Указује се на промену перспективе јунака, Симеона Газде, у судару са сличном, здраворазумском, „чуварном“, свешћу српског сељака као метонимијске одреднице народа. Тај додир симеонске трговачке и здраворазумске сељачке логике испоставља се као кључна тачка разумевања победе као превазилажења традиционалистичког схватања херојства и жртве.

Кључне речи: Злайно руно, победа, пораз, Косово, Први светски рат, дискурс.

Посматрајући почетком октобра 1915. године са своје диванхане бомбардовање Београда што га врше аустроугарски монитори, Симеон Газда по ко зна који пут у симеонској историји салдира инвентар штете док куће и миљуци (као у Москопољу 1769. године, као с почетка Првог српског устанка, као у навали „небеске Скитије“ 1862. године) нестају пред његовим очима у 
чељустима ватре, тог древног душманина Његована. Али, док то чини, Симеон Газда истовремено се суочава са оним што одређује његов живот - рачуницом. Само што сада не рачуна на мало, нема у виду трговачке контракте и пословне спекулације. Сада он рачуна en grosse - своди биланс српске победе у Великом рату и пре него се она догодила. Јер, иако све око њега гори, иако Аустријанци надиру преко Саве и Дунава, а Београд ће обавити трогодишњи мрак окупације, сиромаштва, страха и глади - Симеон Газда не сумња у коначну српску победу. Не би, иначе, његов син и наследник Стефан, по судбинској одлуци Фирме као организма који живи за себе, аутономно промишља и одлучује, избегао на време да тој истој Фирми продужи живот. И опет до коначне победе. Други рачун своди те октобарске вечери Симеон Газда, онај рачун који представља вечну дилему успешног пословног човека - је ли нешто што се желело и што ће се на крају, на овај или онај начин, добити, плаћено скупље него што вреди? Шта је прихватљива цена победе? Вреди ли та коначна победа - у коју Симеон Газда нимало не сумња - толиких жртава, људских и материјалних? Може ли се пораз - тренутан а неминован - претворити у коначну победу? Али, још судбоносније, може ли се коначна победа испоставити излишном и водити неком још судбоноснијем поразу?

Све ово представља такође и суштину агона који се одвија између Симеона Газде с једне, и генерала Живковића и његовог начелника штаба пуковника Лазаревића с друге стране. На једном полу јасно исказано симеонско начело да се „национални интереси најуспешније бране добрим трговачким билансом“, а на другом војничко схватање да је „једино начело - победити по сваку цену“. ${ }^{1}$ Но, овај агон се у темпоралној трансверзали „до-

1 Borislav Pekić, Zlatno runo I, Laguna, Beograd 2012, 320. 
зива“ са агоном који је Газдин деда, Симеон Лупус, још 1842. године водио са својим кумом Илијом Гарашанином. Овај паралелни наратив (што је једна од кључних одлика Пекићевог наративног модела у Злайном руну) једну микротемпоралну секвенцу - борбу за Београд октобра 1915. године - трансформише у макротемпоралну сферу - косовски бој који се у свести Срба не одвија у једном временском одсечку (Видовдан 1389. године), већ у свевремености. У том агону са Гарашанином Симеон Лупус заступа гледиште да косовски пораз никаквим митотворачким трансцедентирањем не може бити претворен у победу, чак ни као симболичка ознака националног бића. Јер, оно што је митско, то је запретено у дубини националне свести, и самим тим невидљиво и неспознајно, па онда и не може бити искуство које помаже у историјским процесима. Митско, другим речима, није историјска реалема, већ тзв. историјска фикција, заправо скуп представа о историјском значењу одређеног догађаја. Са симеонске тачке гледишта, те представе не узимају у обзир оне „онтолошке крајолике“ који су нужно антиподни, и „у којима се прави разлика између сакралних и световних нивоа стварности“.2 У таквом херојском (митском) наративу нема места за промишљање практичне употребе и домета тог мита у политичкој и историјској сфери. Трговачким речником Симеона Лупуса речено, „Косово не може бити роба за излог“, јер: „Што је за углед, то је и за дику. Што за дику, то и за углед. Не може се човек нечим дичити, а да се на то и не угледа. А не можемо се, јер нисмо шашави, на Косово угледати...“3

2 Thomas Pavel, "Fiction and the ontological landscape", Studies in Twentieth Century Literature, 1982, VI, 1-2, 161.

3 Borislav Pekić, Zlatno runo IV, Laguna, Beograd 2012, 364. 
Тој „симеонско-курвинској“ логици супротстављена је Гарашанинова „косовско-буздованска“ логика, која настоји да нешто што је несумњиви историјски пораз, чак катастрофа (јер није у питању само изгубљени бој, већ почетак пропасти српске средњовековне државе), осмисли у ванвременском, митском, чак епифанијском дискурсу: „За угледање Косово, наравно, није, ако ћемо га третирати као војени пораз, али ако на њега гледамо као на израз приправности једног нацијона да између живота у ропству и смрти у отпору изабере друго, за понос јесте“.4

Ова разделница двеју паралелних а недодирујућих дискурса победе/пораза пресликава се, дакле, у расправи Лупусовог унука Симеона Газде са српским официрима. Чак су и аргументи исти. Газдин став да „нацију не чине људи, него њихов посед“" судара се са ставом генерала Живковића да је узалудна одбрана Београда и неминован пораз у тој борби „историјски кредит“б који ће бити уложен у будућу победу. То је управо оно што на уму има и Илија Гарашанин, који се позива на „моралне обзире који политици једног нацијона дају исторически смисао“.7 Управо тиме одлуку о одбрани Београда образлаже генерал Живковић: „Повлачење без борбе би нам уништило морал. А без морала никакви фронтови не користе“. А као што се на временској трансверзали од седам деценија сустичу дискурси Илије Гарашанина и генерала Живковића, тако се на истој тој трансверзали сусрећу симеонски дискурси, кроз став Симеона Лупуса

\footnotetext{
4 Исто, 364.

5 Borislav Pekić, Zlatno runo I, 321.

6 Исто, 321.

7 Borislav Pekić, Zlatno runo IV, 363.

8 Borislav Pekić, Zlatno runo I, 320.
} 
да је „за народ који зна шта ради, за његове државнике са зрном соли у памети, важније да им политика буде добра, па макар морал мало и шантао, него да имају реноме свеца у историческоме гробу“, унука Симеона Газде да ће Срби „остати са моралом, али без људи, са Фирмом, без робе. Град ће бити сатрвен да би се одржао морал који више неће имати ко да употреби“" ${ }^{10}$ Трговачки ум Симеона Газде у томе препознаје gамйuн $\bar{\imath}$ - спекулацију којом нека фирма, ради дугорочне добити и йоঠege над конкуренцијом, жртвује извесну количину робе продајући је готово будзашто. Али, постоји ограничење које Симеон Газда - узалуд - покушава да објасни генералу Живковићу: „Дампингом могу да се служе само богате и моћне фирме. Руси и Немци могу да врше дампинг. Мало предузеће као што је наша Сpбија нема за такву трговину довољно робе на лагеру“. ${ }^{11} \mathrm{y}$ овом исказу Симеона Газде историјска фикција Злайноі руна с јесени 1915. године предестинира историјску реалност с краја Првог светског рата - милионе страдалих Срба без које је биолошке супстанце нација ступила не само у новостворену државу, већ и у нову политичку и историјску реалност постратне Европе. Тако се показује да је историјски роман (а то Злайно руно једним добрим делом јесте) можда само историјска фикција, али да његово разумевање може - и мора - бити историјско, дакле афикционално. ${ }^{12}$

При свему томе, с обзиром да је Симеону Газди дата - јер у себи садржи све Симеоне од Москопоља до његовог доба - способност паноптичког виђења,

9 Borislav Pekić, Zlatno runo IV, 363.

10 Borislav Pekić, Zlatno runo I, 320-321.

11 Исто, 321.

12 Видети: Eric Donald Hirsch Jr., "Three Dimensions of Hermeneutics", New Literary History, 1972, 2, 249. 
бива разумљиво што је његов дискурс надмоћан - мада несврховит - у овом агону. Апсолутно неразумевање Газдиних разлога од стране генерала Живковића и пуковника Лазаревића, пак, потиче од транспарентности херојског (митског), „косовско-буздованског“ историјског обрасца наспрам привидно нетранспарентне економско-трговачке, „симеонско-курвинске“ логике. ${ }^{13}$ С једне стране стоје апсолутне и неупитне, а подразумеване вредности косовског мита који производи официрску свест као ауторитарну и наметнуту чак и самим егзистенцијалним разлозима. Свест, пак, коју поседује Симеон Газда (и сви Симеони пре њега) такође је апсолутна, али рационално заснована и самим тим просветитељска, дидактичка. Ако је херојска (митска) свест симӣйом историјске предестинираности и судбинске неминовности (па се косовски бој неће завршити до неке вечне и непорециве победе, која је наравно немогућа и недостижна), онда је просветитељска (симеонска) свест феномен самооспољавања историјске рационалности (у којој је логични свршетак косовског боја као пораза неминовни предуслов за будуће победе)! Ако је битно обележје херојског (митског) дискурса победе каузалности, онда је обележје њему супротстављеног рационалног (симеонског) дискурса победе

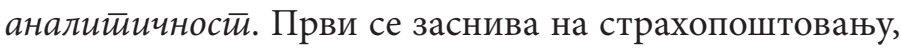
други на скептичној дистанци. Први дискурс је наиван, други је, пак, критички, стабилишући. Први је нестратешки, кратковид, усмерен ка непосредном циљу: победити без обзира на људске и материјалне жртве. Други је спекулативан и далековид, усмерен ка дугорочном

13 Теорију транспарентности као односа фиктивних ликова према тзв. историјској реалности видети у: Arthur Danto, The Transfiguration of the Commonplace: A Philosophy of Art, Cambridge (Massachusetts) 1981, 157-166. 
циљу: победити уз очувану супстанцу у људским и материјалним ресурсима.

Па ипак, ако је официрско неразумевање Симеонових разлога митским дискурсом одређено и огољено, и симеонски дискурс делом почива на неразумевању супротних становишта. Рационални дискурс, наиме, треба да уравнотежи и деривира херојски (митски), али га не може поништити. Јер, дугорочне и трајне победе, оне судбинске, ипак не може бити без малих, наизглед неважних победа. Победник напросто мора бити и жртва - не нужно у истом бићу, али у истој онтолошкој перспективи. Жртва је, дакле, неминовна (и ту је митска свест у праву), али мора бити на крају самерена са победом (ту је, пак, у праву рационална свест).

И баш у том тренутку потпуног неразумевања двају дискурса победе јавља се помиритељ, тзв. „глас народа“. На сцену агона ступа редов-трећепозивац, сељак Спасоје. На позив официра̂ да ступи у разговор са Симеоном, Спасоје у први мах потврђује (али само наизглед) митски образац мишљења и делања. Он је за то да се Београд брани до последње куће, „чија се на правцу нађе “"14 и у том тренутку он је глас митотворачке, „косовско-буздованске“ етике. Међутим, баш у тренутку када је наизглед антагонизовао себе у односу на Симеона, почиње њихово дубље разумевање. Јер, док официри тријумфују, не схватајући да им Спасоје „превлачи штриклу“ преко носа, Симеон је тај који разуме и спознаје шта се крије иза овог йривиgної херојског дискурса: „Симеон је побледео. Какодемонска сељачка памет, ограђена међашима сопствене њиве и равнодушна према свему што се иза брда догађа“. 15

14 Borislav Pekić, Zlatno runo I, 322.

15 Исто, 322. 
У том часу, заправо, Спасоје бива говорник који саопштава, али који - истовремено - у својој надмоћној сељачкој лукавости (да не увреди „господина“, а да задовољи очекивања претпостављених) постаје суштински трансмитер између два антагонистичка дискурса. Важно је, у ствари, оно што Спасоје не изговара, а „ако нешто није изговорено, онда не може да се чује, а ако га нико не чује, онда то није могло бити изговорено“. ${ }^{16}$ И није! Јер, тај сељачки, „народски“ дискурс не садржи се у Спасојевим речима. Оне су тек лисичја лукавост која говорника ништа не кошта, ничим га не обавезује, и ничему не користи. Белодано је јасно да Спасоје не дели светоназор својих официра. Он се ту нашао по нужди - како по нужди војног обвезника, тако и по нужди свога искреног, непатвореног родољубља. Али он своје разлоге не правда позивајући се на морална начела, попут генерала Живковића. Зато управо у том тренутку, када Спасоје наизглед стаје на страну својих официра показујући тобожњи ентузијазам и патриотски жар - управо тада га Симеон сасвим прозире. Он најпре схвата иронију ситуације коју официри нису способни да уоче. Официри, наиме, не виде оно што Симеону бива очигледно: „На кантару је био њихов, а

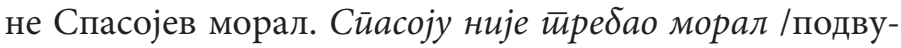
као Б. Ђ./. Он је имао здраву, чуварну памет. Официри нису имали ништа до части... " ${ }^{17}$

Онога тренутка када у Спасоју - сељаку, једном од оних које он, као трговац и пословни човек, челник велике фирме, није рачунао у људе - угледа свога прадеду Симеона Грка, препозна његову лукавост и добро скривану мудрост, тог тренутка и сам Симеон Газда дола-

\footnotetext{
16 Ерик Доналд Хирш, нав. дело, 248.
}

17 Borislav Pekić, Zlatno runo I, 323. 
зи до судбинског сазнања да његова симеонска, здраворазумска и рационална суштина пребива у српском сељаку, за кога рат представља одбрану свога имања, свога дома, своје куће у Мечковцу кога „ни на мапи нема“, ${ }^{2}$ а не борбу за имагинарне идеале, за „крст часни и слободу златну“, за магловиту идеју уједињења. У том часу Симеоново виђење српског народа трансформише се од оне ничеовске „надмоћне свести која суди“ у свест која разуме. Дотадашњи презир према онима који нису ни субјект ни објект трговине, па самим тим не завређују његову пажњу, претвара се у разумевање да та свест - оличена у трећепозивцу Спасоју - јесте иста као његова симеонска, чуварна и рачунџијска, промишљена и здраворазумска. Како у микротемпоралној секвенци једне битке (каква је ова за Београд), индивидуалног страдања и судбине појединца - тако и у макропроцесима самога Великог рата и судбине српског народа: „Симеон се насмејао. Помислио је: победићемо! Не због несавитљивости пуковника Лазаревића, који ће, не сагибајући главу, погинути у једном од многих ровова који нас доле на југу чекају, него због прилагодљивости редова Спасоја, који ће, док пуковник Лазаревић буде гинуо, са главом у блату и говнима размишљати на који начин да прошири своју кућу у Мечковцу. Бар једном се историјска једначина обрнула. Оно што нас је у животу као народ одржало, неће нас убити. И даље ће нас одржавати. Та метаморфична, протејска, симеонска срӣска gуша /подвукао Б. Ђ./!“. ${ }^{19}$

У том тренутку довршена је симеонска метаморфоза. Са том свешћу Симеон Газда коначно постаје Србин! Тек тад, тек у тренуцима када под аустријским бомба-

18 Исто, 323.

19 Исто, 323-324. 
ма страдају његове радње и куће, када се све сурвава у ватру пораза, он спознаје суштину српског, народног бића, и схвата да је овај пораз и његов. Али тиме, најзад, стиче право и да будућа победа буде такође и његова. У том схватању престаје да буде важна појединачна судбина, како једног скромног сељака из Мечковца, тако и богатог трговца и велепоседника. Спасоје дан победе неће дочекати. Умреће само два дана касније, а свећу ће му на грудима запалити управо Симеон. Јер, тек сад су он и један сељак, Србин, постали аgелфи, браћа. Браћа по судбини, браћа по разуму, браћа по животу који су провели са истом, симеонском, рационалном свешћу о вредности људског живота. И о йоঠegu која вреди тек ако живот сваког појединца буде највиша мера људског и националног бића!

\section{ИЗВОРИ}

Pekić, Borislav. Zlatno runo I. Beograd : Laguna, 2012.

Pekić, Borislav. Zlatno runo IV. Beograd : Laguna, 2012.

\section{ЛИТЕРАТУРА}

Danto, Arthur. The Transfiguration of the Commonplace: A Philosophy of Art. Cambridge (Massachusetts) : Cambridge University Press, 1981.

Hirsch, Eric Donald. “Three Dimensions of Hermeneutics”. New Literary History, 3 (1972): 245-261.

Pavel, Thomas. "Fiction and the ontological landscape". Studies in Twentieth Century Literature, VI, 1 (1981): 157-168. 
Bojan Đorđević

\section{THE DISCOURSE OF VICTORY \\ IN PEKIC'S THE GOLDEN FLEECE}

The paper discusses narrative models that model the discourse of victory and defeat based on two narrative sequences of Pekic's novel The Golden Fleece. The antagonism of heroic (mythical) and rational (Simeon-like) awareness of the price of victory, its value and meaning are demonstrated. The paper highlights a change in the perspective of the hero, Simeon the Landlord, in a collision with a similar, common sense, "guardian" consciousness of the Serbian peasant as the metonymic determinant of the people. This touch of the Simeon trade and common sense peasant logic turns out to be a key point of understanding victory as transcending the traditionalist understanding of heroism and sacrifice. 